\title{
Taking the minimum content seriously: Hart's liberalism and moral values
}

\author{
GAVIN BYRNE
}

Birmingham Law School*

$\mathrm{I}_{\mathrm{sin}}^{\mathrm{n}}$

n spite of its immense reputation, H L A Hart's legal philosophy is rarely examined as a single, coherent body of work. The Concept of Law tends to be discussed on its own, separate from Hart's liberal critiques of substantive law. Hart himself regarded these projects as distinct. This essay will unite Hart's descriptive project with his critical commentaries. As such it runs contrary to the manner in which Hart's work is normally presented and perhaps the way in which he intended it to be read. Yet, as Nicola Lacey's biography explains, Hart saw himself as a liberal perhaps above all else. ${ }^{1}$ It is important, therefore, that his descriptive project fits with the various critical positions that he espouses elsewhere to form a coherent liberal whole. A central tension emerges in Hart's writings when they are read in this way. It relates to Hart's position on the status of moral values, an aspect of Hart's legacy that is largely overlooked. ${ }^{2}$

Much has been made of Hart's supposed scepticism in relation to the objective truth of moral values. Hart claimed to be non-committal on this issue. ${ }^{3}$ Yet Hart provides fact-based reasons for certain core moral values, a position that renders such values objectively true. This essay begins with an expositional analysis; Hart's scepticism in this regard has been misunderstood. Hart was sceptical as to the usefulness of debate on the objective status of moral values, but his own position requires a commitment to such values. As such, many values that he espouses in his critical comments about law are best understood as objectively true.

Once this preliminary point is dealt with we move on to a central tension in Hart's writings and the core argument in this essay. Hart embraced a form of political liberalism that requires the existence of lasting moral values. On the other hand, Hart goes to great lengths to emphasise the contingent nature of the values discussed in chapter IX. This tension goes to the heart of liberal positions. Liberalism wishes to promote tolerance of multiple viewpoints and avoid moral absolutism, yet the only way in which this worldview

* I am immensely indebted to Sean Coyle for very helpful feedback on multiple versions of this paper. I would also like to thank Gordon Woodman, Steve Smith, Martin Borowski, James Lee and attendees at the jurisprudence section of the 2010 Society of Legal Scholars conference for comments on earlier drafts.

1 N Lacey, A Life of H L A Hart: The Nightmare and the Noble Dream (Oxford University Press 2004) 68, see also 36, 171 and 195.

2 Recent exceptions include A Perreau-Saussine, 'An Outsider on the Inside: Hart's Limits on Jurisprudence' (2006) 56 University of Toronto Law Journal 371; and S Delacroix 'Meta-Ethical Agnosticism in Legal Theory: Mapping a Way Out' (2010) 1(2) Jurisprudence 225

3 H L A Hart, The Concept of Law (2nd edn, Oxford University Press 1994) 254, see also 168. 
can be advanced is by committing to lasting moral values such as the protection of fundamental freedoms. I argue that Hart's legal philosophy, viewed as a whole, provides us with a mechanism for the support of lasting liberal values about the specific content of law.

The manner in which Hart's position ultimately supports lasting critical moral values about the content of law casts doubt on his general approach to legal philosophy. In my concluding remarks I note how any contemporary Hartian faces a choice between following Hart's liberalism or following Hart's sharp distinction between analyses of what law is and what law ought to be.

\section{Objective truth of moral values}

A number of commentators discuss Hart's supposed scepticism about the objective truth of moral values. Leiter points to a tension between such scepticism and Hart's 'soft' positivism. ${ }^{4}$ Raz argues that certain weaknesses in Hart's concept of law result from his 'rejection of evaluative objectivity'. ${ }^{5}$ Perreau-Saussine suggests that Hart was uncomfortable with his 'doubts that . . . objective morality exists'. ${ }^{6}$ In this section I show that Hart's work supports the existence of objective moral values. A far bigger problem for Hart, as for all liberals, is the issue of whether such values are lasting. ${ }^{7}$

Hart never attached a specific label to his meta-ethical position. A number of commentators have done so. There is general consensus that Hart endorsed a naturalist meta-ethics. ${ }^{8}$ This labelling is useful as it helps to draw out some of the implications in Hart's claims. Many of the same commentators that categorise Hart as a naturalist, have also claimed that Hart is a sceptic about the existence of objectively true moral values. This suggestion makes little sense; such a position requires the existence of at least some objective moral values. In this section I demonstrate that objectivity about moral values is also the most natural reading of various claims that Hart makes. Locating Hart's meta-ethics within naturalism is useful for a second reason. The specific type of naturalism that Hart tacitly endorses has difficulty with the idea of moral values that are necessary or even lasting. It is the idea that certain core moral values might be hostage to change that really troubled Hart as a liberal.

The Concept of Law chapter IX is Hart's most sustained discussion of the relationship between law and morality. Hart explains why we can expect a degree of overlap between the substantive content of law and certain basic moral principles. In doing so he warns against the conclusion that legal systems must embrace certain values in order for their rules to count as law at all. This leaves the question of whether there are moral values that always ought to be embraced by a legal system, even if we accept that they do not need to be embraced in order for such a system to count as law. I return to this specific issue in the next section. For now let us consider how the argument in chapter IX and elsewhere displays the basic traits of reductionist naturalism about moral values.

4 Brian Leiter 'Legal Realism and Hard Positivism' in J Coleman (ed), Hart's Postscript: Essays on the Postscript to The Concept of Law (Oxford University Press 2001) 355-70, in particular 361-3.

5 J Raz, 'Two Views on the Nature of the Theory of Law: A Partial Comparison' in Coleman (ed) (n 4) 1-38, at 5-6.

6 Perreau-Saussine (n 2) 386-8.

7 The terms 'positive' and 'critical' morality are Hart's; moral philosophers speak of descriptive morality, the values a particular society holds, and normative morality, values we ought to hold. Discussion of 'moral values' herein should be understood in the normative sense.

8 See D Priel, 'Were the Legal Realists Legal Positivists?' (2008) 27(4) Law and Philosophy 309, at 330-2; Raz (n 5) 6; and Delacroix (n 2) 225-30. Priel notes that Hart looks to social practices in order to explain obligation. This is also a naturalist methodology, but the focus of this paper is on the nature of moral values themselves. Delacroix attributes 'bald naturalism' to Hart. 
(a) Source of Moral Values

Reductionist naturalists hold that moral values come from non-moral facts about the world. Hart acknowledges that viable legal systems will have certain specific content in common with accepted moral values. 'Truisms' relating to the facts of our existence impact upon the substantive content of law and morality as systems of social ordering. Hart's explanation of reasons as to why we hold certain moral values is typical of reductionist naturalism. Survival is a 'good' that we seek to achieve. Facts about the physical world and human nature impact upon how that goal can be achieved. The content of core moral values reflects the pursuit of this good as impacted by the practicalities involved. ${ }^{9}$

(b) Empiricism

Reductionist naturalists seek empirical proof for matters of fact; the truth of a moral value is only accepted if there is empirical evidence for the underlying fact that it reduces to. Hart holds that 'truisms' of law and morality are not necessary, universal truths or teleological ends of man. His claims are expressly non-metaphysical. ${ }^{10}$ When we look throughout human history man actually has sought survival as a matter of observable fact; survival as a good to be pursued has played and continues to play a central part in all of our ordered affairs, how we interact and how we understand the world around us. ${ }^{11}$ Similarly it is an empirical fact that human beings are vulnerable to physical harm. As a result, we have the generally accepted moral value that one should not physically harm another human being. Throughout his writings Hart embraced empiricism with regard to underlying non-moral claims used in support of moral arguments. In Social Solidarity and the Enforcement of Morality ${ }^{12}$ Hart argues against the claim that unless the positive morality of a particular society is enforced through law that society is likely to disintegrate. Hart points out that this thesis lacks empirical evidence.

(c) Scientific evidence

Reductionist naturalists use the sciences to inform their moral positions. ${ }^{13}$ In the manner of reductionist naturalists, such as Peter Railton, Hart is willing to have his philosophy led by developments in physical and social sciences. Hart sees the issue of how we come to accept and adopt moral values as a question

9 Hart, Concept (n 3) 174-200. Hart follows Hobbes in 'lower[ing his] sights' to explain moral values. The fact that human beings seek survival is a common starting point; Hart emphasises the special place this holds in human endeavour: ibid 191-3. In this respect Hobbes is a forerunner of reductionist naturalism in meta-ethics.

10 Ibid 192.

11 Ibid. For Hart, that 'we are not a suicide club' must be presumed in any discussion of human ordered affairs; Peter Railton makes a similar claim in his explanation of reductionist naturalism, see 'Moral Realism' (1986) 95(2) Philosophical Review 163, at 181.

12 H L A Hart, Essays in Jurisprudence and Philosophy (Oxford University Press, 1983) 248-62. We can see Hart's distrust of moral claims that lack empirical bases elsewhere, see H L A Hart, Law, Liberty and Morality (Oxford University Press 1963) 58-60.

13 Reductionist naturalists are not 'scientists'; they do not hold that the sciences provide all answers to questions posed in moral philosophy. They simply use sciences to inform claims about value and rationality. See Peter Railton, 'Naturalism and Prescriptivity' (1989) 7(1) Social Philosophy and Policy 151, at 159-60. 
for 'psychology and sociology'. ${ }^{14}$ This willingness to incorporate scientific fact into critical moral argument is a consistent feature of Hart's work. ${ }^{15}$

(d) Revisability

For the reductionist naturalist facts are contingent. The best that we can say about a matter of fact is that it is empirically verifiable as true for the time being. Should the truth value of an underlying fact change, the truth value of the corresponding moral value would also change. ${ }^{16}$ Moral values are thus revisable. For Hart, human beings might have evolved so as to be impervious to physical harm, resources might have been or might one day be limitless and human beings might have evolved or yet evolve so as to be radically different physically. Certain moral values are deeply embedded in our thought and language because of matters of fact, but Hart takes these facts to be contingently true. ${ }^{17}$

This brings us to the objectivity issue. Reductionist naturalism holds that moral values are objective; certain things are human aims, certain non-moral facts about the world enable us to pursue those aims. Moral values are reducible to a combination of objective non-moral aims and objective non-moral facts. ${ }^{18}$ If Hart really is a reductionist naturalist when it comes to moral values, he would need to hold that at least some such values are objective. Hart expressly avoided this issue. ${ }^{19}$ Yet there are a number of reasons why the values he discusses in chapter IX should be considered objective.

Hart treats the aim of human survival as an observable fact; human beings simply 'do wish to live, even at the cost of great misery'. ${ }^{20}$ We are committed to this aim in our very

14 Hart, Concept (n 3) 193-94. Hart's review of J L Mackie's Ethics: Inventing Right and Wrong (Penguin Books 1977) is also consistent with this aspect of reductionist naturalism, see H L A Hart 'Morality and Reality', New York Review of Books (9 March 1977) 35. Hart endorses Mackie's explanation of moral values; mankind becomes disposed to act in particular ways because 'human beings are competitive with and vulnerable to one another, living in a world of scarce resources', morality becomes a 'device which by counteracting human egoism provides some of the essentials of human welfare', ibid 38. Hart is unconvinced that the alleged 'queerness' of ethical objects is tantamount to an argument against their existence. He also criticises Mackie for understanding the nature of morality as an intelligent creation with little explanation of the part played by human emotion. Railton's two major points of disagreement with Mackie are similar. Railton disagrees with the idea that there is anything 'queer' about moral values when taken to supervene upon non-moral goods, 'Moral Realism' (n 11) 171-7 and 183-4. Railton also disagrees with Mackie's conceptual point about moral facts requiring the existence of objective and categorically prescriptive facts. For Railton, emotion plays a part in how we get from needs and wants to moral values: ibid 183-9 and 200-4

15 Hart, Law, Liberty (n 12) 68-9, and the postscript to Punishment and Responsibility (2nd edn, Oxford University Press 2008) 210.

16 Railton, 'Moral Realism' (n 11) 198-201, see also Railton, 'Naturalism’ (n 13) 158-9. This does not require a theory of moral progress. Moral values transform to reflect changes in our environment and needs; there is no reason to assume that we are getting morally better, see Railton, 'Moral Realism' ( $\mathrm{n}$ 11) 195.

17 Hart, Concept (n 3) 193-200.

18 Railton, 'Moral Realism' (n 11) 173-84. Railton claims that there is a 'reduction basis' for our beliefs as to what will produce a good or desirable sensation. This is a combination of the qualities of the individual, the object or phenomenon experienced and other factors such as context. This explains subjective wants. Railton posits the idea of an 'objectified subjective interest' to explain moral values. Objectified subjective interests are those that an idealised version of an actual individual would wish their non-idealised self to hold. Such interests are intrinsically good for the non-idealised individual. Objective moral goods involve interests of two or more people.

19 Hart, Concept (n 3) 168 and 253-4.

20 Ibid 192. 
'structures of thought and language'. ${ }^{21}$ Yet Hart's claim about survival as a human aim goes far deeper. No discussion of morality makes sense unless we accept survival as a basic human goal. It simply has to be good for us to survive, because any discussion of what we ought to do as a group is premised on the idea that 'we are not a suicide club'. For there to be morality at all, our continued survival must be accepted as an objective 'good' rather than a matter of subjective preference.

Hart then discusses 'truisms' that impact upon the achievement of survival. Hart does not explicitly describe these as objective, but he presents them as such. Human vulnerability, approximate equality and limited altruism are said to be 'salient characteristics' of human nature; we do not merely believe these things to be true. Throughout the analysis Hart refers to these truisms as facts, 'men are . . vulnerable to bodily attack', 'no individual is so much more powerful than others', 'men are not devils', 'human beings need food, clothes and shelter'. ${ }^{22}$ The most natural reading of these claims is that they do not depend on the conscience of an observer for their truth.

This, then, is the first reason why the moral values discussed in chapter IX should be thought of as objective. The whole thrust of Hart's argument is that core moral values are rooted in fairly banal facts about physical nature and our world, facts that both law and morality reflect. Objective truth simply means true in virtue of some set of facts about the world. In explaining the commonalities in substantive content throughout moral and legal codes Hart rooted these values in the world rather than in us.

The second reason is the inherent oddness of any alternative. In his analysis Hart makes it clear that he is providing reasons for moral values rather than causes of those values. Hart explains why we do hold certain 'universally recognized' core principles. This method of explaining the 'core of good sense' in natural law, also (perhaps inadvertently) justifies the moral values under discussion. Given that Hart provides a set of reasons for holding certain moral values, it seems impossible for him to accept any moral position according to which we ought not to hold these values provided the underlying facts continue to hold. Hart cannot argue against the view that we ought not to kill other human beings or that we ought to protect personal property without arguing against his own good reasons as to why we generally do hold these values.

To be a sceptic about the objectivity of these particular values, Hart would have to accept the counter-intuitive position that the reasons for such values are objective, but the values themselves might not be. If Hart wished to commit strongly to scepticism about all moral values, a very complex argument was required at this juncture. Such an argument is not provided.

Of course, Hart is free to accept that not all moral questions will have a single right answer; objective moral values may clash, which would involve a weighing-up process on the part of an individual. ${ }^{23}$ This is not to deny that the moral values themselves are objective, it merely means that they conflict from time to time. Furthermore, Hart could accept that not all moral propositions have objective bivalence. There may be moral values that cannot be explained in the same way as those discussed in chapter IX. In this weaker sense, then, Hart may have been a sceptic when it comes to objective moral values, but scepticism about the objectivity of all moral values fits poorly with his analysis.

21 Hart, Concept (n 3) 192.

22 Ibid 194-9.

23 Railton notes that there may be different goods to weigh up each of which is objective and appealing. Railton distinguishes 'a good for A' (objective moral values) from 'the good for A' which an individual might decide upon by balancing objective values, 'Moral Realism’ (n 11) 176. 
Any tension in Hart's writings or discomfort that he may have had about the nonexistence of objective moral values is easily addressed from within his own work. Hart's own comments reveal less scepticism about moral objectivity than they do scepticism about the very question of such objectivity. Quite simply, Hart felt that there was little to be gained in endless debate as to whether moral values ultimately come from within us or external facts about the world. Hart did not need to defend a position on objective moral values to respond to his critics. ${ }^{24}$ In his review of Bernard Williams' Ethics and the Limits of Philosophy, Hart briefly addressed the issue of why meta-ethical arguments should matter; he was unconvinced that debates as to the objectivity of moral values were of practical significance. ${ }^{25} \mathrm{~A}$ far bigger problem for the consistency of Hart's overall position relates to the contingency of moral values. This is a separate issue. It is an entirely tenable position that moral values are objective, yet contingent. This is a core commitment in the reductionist naturalism that we have been using to unpack Hart's meta-ethics. That moral values are 'revisable' accepts that they are objective because when true they relate to a set of facts about the world, but it also requires that they are contingent because those underlying facts are hostage to change. We have seen here that Hart accepts that moral values are revisable. This raises a particular challenge to liberalism. As I shall show in the next section, liberalism of the sort that Hart wished to endorse needs to be confident that some core moral values will hold from one generation to the next.

\section{Revisable moral values and Hart's critical position}

Hart comments critically on law. If there is to be consistency in Hart's position these moral claims come with the commitments attached to them in chapter IX. There are objective reasons for these moral values and as such they can be described as objectively true. Nevertheless, this truth is contingent. This contingency exposes an underlying tension between Hart's argument about the minimum content of natural law and his general liberal worldview.

\section{A. THE HARM PRINCIPLE}

Mill's harm principle is a key element in Hart's work. For Mill, 'the only purpose for which power can be rightfully exercised over any member of a civilized community, against his will, is to prevent harm to others' ${ }^{26}$ Hart endorses this approach in debate with Lord Devlin on the Wolfenden report.

Hart supports the recommendation that homosexual acts between consenting adults and conducted in private should not lead to criminal sanctions. Hart does so on the grounds that such acts do not cause demonstrable harm to others. Devlin claims that social harms would be caused by what was at the time an affront to popular positive morality. Hart demands empirical evidence. ${ }^{27} \mathrm{He}$ also argues that requiring an individual to repress their sexual orientation is likely to cause that individual pronounced psychological harm. ${ }^{28}$

The harm principle is as objectively true as the claim that any good flourishing legal system will include laws against harming others if read in light of Hart's claims in chapter IX. The reasons for one provide reasons for the other. The same argument holds that these

24 Hart, Concept (n 3) 254. 'For practical purposes', as Hart puts it, a judge ought 'to make the best moral judgment he can on any moral issues he may have to decide' regardless of whether objective moral truths exist.

25 H L A Hart 'Who Can Tell Right From Wrong?', New York Review of Books, 17 July 1983, 49, at 52.

26 J S Mill, On Liberty (Basil Blackwell 1948) 8.

27 Hart, Law, Liberty (n 12) 68-9.

28 Ibid 21-2. 
reasons, and hence this moral value, are contingently true. As Hart notes if men were to lose their vulnerability to each other there would vanish one obvious reason for the most characteristic of provision of law and morals: Thou shalt not kill. ${ }^{29}$ We can see an objective reason for the harm principle in chapter IX. This too would vanish in such an eventuality.

Hart speculates that we could, or could have, evolved so as to develop a hard exocrine skeleton that renders us impervious to any sort of physical harm. In this situation, the harm principle would be in jeopardy as a moral value, at least in relation to physical harm. In a less extreme form we can speculate as to more likely changes in the state of human vulnerability that might have a knock-on effect for the minimum content of natural law and for the harm principle as a critical moral argument about law. Respected scientific discussion is now taking place as to attainable forms of human immortality or a severe diminution in human vulnerability. ${ }^{30}$ These advancements are far from imminent, yet they are sufficiently on our horizon to merit theoretical consideration. ${ }^{31}$ If facts surrounding human vulnerability were to change, so must the scope and shape of any moral argument about law that is based on the idea of human vulnerability under the account of reasons for moral values that Hart espouses.

Some types of harm discussed in Law, Liberty and Morality are distinct from the physical harm mentioned in The Concept of Law. ${ }^{32}$ Nevertheless, if we must hold open the possibility that our vulnerability to physical harm might change, we should also hold open the possibility that we could immunise ourselves from the sorts of psychological harm that Hart mentions in his debate with Devlin. There are corresponding medical advancements in this area too. ${ }^{33}$

The same issue arises in relation to arguments based on scarcity of resources, approximate physical equality, limited altruism and limited understanding and strength of will. If these observable features of human nature are hostage to change, so is any moral argument about law's specific content that depends upon them. We can see how the nature and scope of these facts might change in light of recent research. Let us take the fact that resources are limited. In ongoing debates as to the benefits of genetic engineering in crops,

29 Hart, Concept (n 3) 195. What such an eventuality would do to man's pursuit of survival is moot. If we were physically invulnerable, it seems that our survival would be all but guaranteed and so the pursuit of this goal would lose significance. Hart does not discuss the interplay between vulnerability as a contingent truth and survival as a centrally important goal; it is beyond the remit of this essay to do so.

30 This is due to advances in nanotechnology (see R Freitas Jr, R Merkle, Kinematic Self-Replicating Machines (Landes Bioscience 2004)), cryonics (see B P Best 'Scientific Justification of Cryonics Practice' (2008) 11(2) Rejuvenation Research 493), computational neuroscience (see R Kurzweil, The Singularity is Near: When Humans Transcend Biology (Viking Press 2005)), and cybernetics (see K Warwick, M Gasson, B Hutt, I Goodhew, P Kyberd, H Schulzrinne and X Wu 'Thought Communication and Control: A First Step using Radiotelegraphy' (2004) 151(3) Institution of Electrical Engineers Proceedings on Communications 185). Hard exocrine skeletons for human use continue to be improved, see Cybernetic Inc's HAL® 5 type B.

31 See J P Dupuy 'Some Pitfalls in the Philosophical Foundations of Nanoethics' (2007) 32(3) Journal of Medicine and Philosophy 237; J Davis, 'Life-extension and the Malthusian Objection' (2005) 30(1) Journal of Medicine and Philosophy 27; C Lafontaine 'The Postmortal Condition: From the Biomedical Deconstruction of Death to the Extension of Longevity' (2009) 18(3) Science as Culture 297.

32 Space does not permit analysis of 'harm'. Joel Feinberg discusses its meaning in relation to the harm principle; see The Moral Limits of the Criminal Law, Vol 1: Harm to Others (Oxford University Press 1984) 31-7. For Feinberg, harm here means the wrongful setback of another's interest, at 36. Interest is understood as anything in which an individual has a stake, at 33-4. This will suffice as a working definition and includes psychological harm.

33 Consider the growth in antidepressant medications available and increased prescription of such medications, see 'Explaining the rise in antidepressant prescribing: a descriptive study using the general practice research database' (2009) British Medical Journal 339: bmj.b3999. The rise in use of antidepressants raises many issues, including the desirability of a society immune from emotional pain, see C Barber, Comfortably Numb: How Psychiatry is Medicating a Nation (First Vintage Books 2009). 
those in favour have claimed that this has the capacity to end world hunger thus making the resource less limited. ${ }^{34}$ In this situation, moral arguments about law's specific content that are premised on the idea that our resources are limited would no longer carry weight in relation to this resource. On the other hand, many resources are far scarcer than they were when Hart wrote The Concept of Law. In relation to these, scarcity-based arguments are likely to become more significant as critical commentary on law. ${ }^{35}$

\section{B. LIBERALISM}

Hart's argument against Devlin borrows from Mill; this is far from the only example of Hart's liberalism. McCormick ${ }^{36}$ and Ryan ${ }^{37}$ each document the liberal underpinnings in Hart's moral critique of law, Lacey repeatedly asserts that Hart's politics were 'steadfastly liberal' 38 and, on numerous occasions, Hart used Mill and Bentham as starting points for critique of positive law.

Liberalism encompasses a wide variety of views. At its core it involves a tension between the vision of an open society and liberalism as a practically achievable political goal. The ideal of liberalism is based on individual freedom and value neutrality. It is for the individual to determine their own moral values and live their lives accordingly; no one person's moral outlook should trump that of another. We can see this vision in Hart's argument against Devlin; it is not for the moral majority to determine what is right in terms of sexual practices. Nevertheless, one cannot meaningfully critique law from a liberal perspective and avoid committing to ideas that ought to be protected as lasting values. Typically, liberal critique involves commitment to the protection of fundamental freedoms such as freedom of religion, freedom of expression, freedom of association and freedom of conscience.

Hart's liberalism cannot avoid this tension. Hart cites the French Declaration on the Rights of Man and the United Nations Declaration on Human Rights as the great liberal achievements in positive law. ${ }^{39}$ To endorse these documents one must hold that the values contained within them are in some sense lasting. If the truth of all moral values were to be revisable, in the manner of the harm principle, then it seems difficult to support the fact that some are enshrined in lasting bills of rights and constitutions. Such enshrinement would be a bad idea if the general moral values articulated therein were hostage to radical change. While legislation and precedent are sources of law that we might expect to change over time with changes in underlying facts about the world, declarations on human rights, bills of rights and constitutions are different. Their very purpose is to present lasting, fundamental values that will act as guidelines for legislators far beyond our own generation, come what may in the future.

Hart's philosophy may be able to support objective moral values. This presents no problem to a reductionist naturalist. Yet Hart needs some liberal values to be lasting too if he wishes to endorse 'the great liberal achievements' or any instrument that permanently

34 See N Borlaug, 'Genetically Engineered Food Could Help End World Hunger' in J Torr (ed), Genetic Engineering: Opposing Viewpoints (Greenhaven Press 2000) 129-36. This claim is debatable; see B Halweil, 'Genetically Engineered Food Will Not Help End World Hunger' in ibid 137-46.

35 For one example of such arguments see B Saul, 'Climate Change; Resource Scarcity: Towards an International Law of Distributive Justice’ in R Lyster (ed), In the Wilds of Climate Law (Australian Academic Press 2010) 71-94.

36 N MacCormick, H L A Hart (2nd edn, Stanford University Press 2008) 17-22.

37 'Hart and the Liberalism of Fear' in M Kramer, C Grant, B Colburn and A Hatzistavrou (eds), The Legacy of H L A Hart (Cambridge University Press 2008) 315-30.

38 Lacey (n 1) 68.

39 H L A Hart, 'Are there Any Natural Rights?' (1955) 64(2) Philosophical Review 175, at 89. 
protects fundamental freedoms. Necessary moral truths do present an inherent problem for reductionist naturalists. ${ }^{40}$

We can see that Hart was concerned about the possibility that moral values might not last. He accepts that there is a serious issue to address when it comes to the concerns of ordinary people who attempt to live up to moral standards 'and to transmit them to their children'. ${ }^{41}$ The expression of this concern is a hint that what really troubled Hart about moral values is that they remain true from one generation to the next. In The Concept of Law, Hart '[sought] to evade [the] philosophical difficulties' relating to the status of moral values, a desire that he re-emphasised in the postscript. In the main text, the specific instance of a philosophical difficulty mentioned is whether moral values are 'immutable principles which form part of the fabric of the Universe' or 'expressions of changing human attitudes'. ${ }^{42}$ This too suggests that a concern at the forefront of Hart's mind, even then, was the question of whether we can say of some moral values that they will last.

In what follows, I argue that a broadly liberal, critical morality about law that cannot be revised to the point of abandonment is possible within Hart's work. Some such moral truths seem inevitable if we robustly commit to Hart's concept of law and his reductionist naturalist account of reasons for moral values.

\section{Lasting liberal values about (Hart's concept of) law}

\section{A. A truth about human nature that Hart CANNOt abandon}

Railton makes the following point:

Revisionism may reach a point where it becomes more perspicacious to say that a concept has been abandoned, rather than revised. No sharp line separates tolerable revisionism and outright abandonment . . . ${ }^{43}$

We are concerned with the possibility of lasting values that might be used to critique law in Hart's philosophy. Hart never suggested that his concept of law was eternal; his aim was simply to clarify the meaning of the concept 'law' as we understand it. ${ }^{44}$ Nevertheless, for the exercise at hand we must take Hart's account of the meaning of the concept as fixed; Hart's critical moral values about law must relate to this account of what law is if his work is to form a coherent whole. 'Fixing' Hart's account of law in this way may puzzle some readers as this is not what Hart himself intended to do. In the context of the exercise at hand, however, it makes perfect sense. We are concerned with uniting Hart's concept of law with his critical comments about law. For these purposes, the critical comments that he makes must be about his concept of law rather than any other. If there are facts about human nature or the world we live in that must persist for Hart's concept of law to work, such facts may be revisable for Hart but not to the point of abandonment. Otherwise, Hart's concept of law itself would need to be abandoned as would all of his critical comments about that concept.

This point has an important consequence if we take Hart's reductionist naturalism about moral values seriously. If a certain fact about human nature cannot be abandoned in Hart's legal philosophy, this fact may provide a reductive basis for objective moral values

40 Railton, 'Moral Realism' (n 11) 198-200 and 'Naturalism' (n 13) 158-66.

41 Hart 'Who Can Tell' (n 25) 52.

42 Hart, Concept (n 3) 168.

43 Railton 'Naturalism' (n 13) 159.

44 Hart does not prescribe rules for the valid use of the term 'law'. As such, he does not define it. Instead he tries to capture the meaning of this concept as we understand it: Hart, Concept (n 3) 213; Hart's private notes as reproduced in Lacey (n 1) 222-27; and D Priel 'Trouble for Legal Positivism' (2006) 12(3) Legal Theory 225. 
about law that cannot be abandoned either. Hart never provided an account of human nature itself to do this work for us, but he did, of course, provide a detailed account of law. Let us consider a simple underlying fact about human nature that Hart's explanation of the concept 'law' requires.

Hart clarifies how law is not simply a set of commands backed by sanctions, but is instead a set of guides for behaviour. ${ }^{45}$ These may be guides for private citizens in terms of obeying criminal law, guides for conduct in private affairs such as making a valid will or contract, or guides directed to officials as to how to conduct themselves in an official capacity. The common point is that legal rules, like any rules, are guides for human beings as to how to behave in various circumstances.

Under this understanding, most human beings, most of the time, must be capable of guiding their own behaviour. There may be examples of people who cannot do so or whose ability is limited in this regard. We frequently talk of those who do not have legal capacity, largely on the basis that their ability to control their behaviour is impaired in some way. There may also be instances in which this capacity to guide behaviour has been compromised, for example, if an individual is suffering from an epileptic convulsion. Hart's empirical approach to reasons for moral values can easily support the idea that an exception should be made where a non-moral fact such as evidence of diminished capacity is empirically observable. Similarly it may be the case that we will have to revise our notions of capacity and our claims as to what the substantive content of law ought to be as we discover more about things like brain function. Yet a revision to the point of abandonment of the general idea that human beings have a capacity to guide their own behaviour would require Hart to also abandon his concept of law. So long as we are interested in critical moral values in relation to what Hart calls law, a capacity on the part of humans to guide their own behaviour must remain in some way. Most elect to conform to rules but there are exceptions - a minority choose to commit criminal acts while most citizens avoid doing so. If the observable facts of social behaviour were different, if we were a society of angels (as suggested by $\mathrm{Raz}^{46}$ ) who conscientiously and deliberately all adhere to the law, members of such a society are capable of guiding their own behaviour albeit that they seem likely to always choose to do so in accordance with criminal law. In a possible set of social facts that Hart imagines - a society of metaphorical 'sheep' that follows rules blindly without very much in the way of reflection - we would still be capable of choosing to behave in a way that conforms to legal rules even if we did so in an unthinking fashion. ${ }^{47}$ Hart's account of the concept of law could not work if the observable facts of the matter were such that all human beings were automata. If most human beings most of the time could not be said to self-govern in terms of their behaviour, then 'guides for human behaviour' would be meaningless. There could be no law for a society of robots which have been preprogrammed to act in a set number of ways, or a society of creatures which are enslaved to instincts that they cannot control.

Hart comes close to stating that, wherever there is law, we will observe this fact: [A legal system is] dependent for its efficacy on the possession by a sufficient number of those whose conduct it seeks to control of the capacities of understanding and control of conduct which constitute capacity-responsibility.

45 Hart, Concept (n 3) 28-9, 89-91, 98, 115-17, 124-5.

$46 \mathrm{~J}$ Raz, Practical Reason and Norms (Hutchinson \& Co 1975) 159.

47 Hart, Concept (n 3) 117. See also 'Negligence, Mens Rea and Criminal Responsibility' in Punishment and Responsibility (n 15) 136-57. It counts as rule-following even if one has not exercised thought. Similarly one might fail to follow a rule because one has failed to think. This failure may be morally blameworthy. 
For if a large proportion of those concerned could not . . f form and keep a decision to obey, no legal system could come into existence or continue to exist. ${ }^{48}$

So there is at least one feature of human nature that we can be guaranteed to observe if Hart's account of the concept of law is to work. ${ }^{49} \mathrm{I}$ shall now demonstrate how some of the values that Hart embraces in his critical commentaries on law depend upon this feature of human nature. For each, I hypothesise as to how these claims and the underlying nonmoral truth could be turned into a critical moral value about law along reductionist naturalist lines. Each of these values fits with a general liberal outlook.

This exercise comes with two important caveats.

The list is non-exhaustive. My argument does not deny the possibility that there may be other non-moral facts that simply must be true if Hart's concept of law is to hold. 50

What follows are mere outlines of moral values. Space does not permit a full defence of these values and that is not the aim of this essay. I merely illustrate how Hart's meta-ethics can be used to generate moral values that cannot be abandoned so long as one commits to his concept of law.

\section{B. THE DOCTRINE OF FAIR OPPORTUNITY}

Hart repeatedly embraced what he terms the 'doctrine of fair opportunity'; law ought not to impose punishment on an individual unless that individual has had a relatively unimpeded opportunity to make their behaviour conform to law. A good example is Hart's argument against Lady Wootton. Wootton argued that the issue of mens rea in criminal law should only be considered at the point of conviction, in order to determine the most socially useful outcome. The basis for this argument was a presumed link between the doctrine of mens rea and traditional retributivist theories of punishment. Wootton assumed that looking into mens rea at the point at which we determine guilt, and therefore looking into the defendant's past mental state rather than his or her present one, implies that sentencing is a means of achieving retribution for past wickedness. Hart makes the following point:

... a primary vindication of the principle of responsibility could rest on the simple idea that unless a man has the capacity and a fair opportunity or chance to adjust his behaviour to the law its penalties ought not to be applied ... Such a doctrine of fair opportunity would not only provide a rationale for most of the existing excuses which the law admits in its doctrine of mens rea but it could also function as a critical principle to demand more from the law than it gives. [emphasis added] ${ }^{51}$

48 Hart, Punishment and Responsibility (n 15) 229.

49 Many would contend that law amounts to more than rules. My discussion does not exclude this possibility. The point is that at bare minimum there must be some human capacity for behaviour guidance for the understanding of law presented in The Concept of Law.

50 I have selected a non-moral fact that seems uncontroversial and that Hart mentions. Other facts that Hart might not be able to abandon include abilities to communicate, understand and reason. A Freudian might suggest that rule-following requires an ego; unfettered id will not provide a mechanism to follow rules other than the pleasure principle. See S Freud, The Ego and the Id, J Riviere and J Strachey (trans) (Hogarth 1962) and New Introductory Lectures on Psychoanalysis, J Riviere, J Strachey and A Richards (trans) (Penguin 1991) 102-12. Hart alludes to the possibility that psychological truths may be necessary for rule-following, Concept (n 3) 193. Any of these facts could be coupled with a non-abandonable good and used as a reduction basis for moral values. This is to say nothing of the range of values that might emerge if we were to follow Epstein in pressing Hart beyond his original parameters based on survival to include the maximisation of social welfare as a general human aim, see R A Epstein 'The Not So Minimum Content of Natural Law' (2005) 25 Oxford Journal of Legal Studies 219.

51 See Hart, Punishment and Responsibility (n 15) 158-85, at 181. 
So positive law only ought to penalise individuals in situations in which they have been able to exercise free choice. ${ }^{52}$ This is a critical moral value to guide existing legal systems.

We can see a similar commitment to fair opportunity in Hart's debate with Devlin. Hart distinguishes the repression of sexual impulses from the repression of other desires. ${ }^{53}$ One may be tempted to steal, but unless one happens to be a kleptomaniac, one can freely choose to repress this desire. One might repress one's sexual impulses by not acting upon them, but the impulse itself is 'a recurrent and insistent part of daily life'; it is not something that one can exercise control over. ${ }^{54}$ Criminalising sexuality causes a specific type of harm because one cannot choose one's sexual orientation in the same way that one can choose to steal or refrain from doing so. The human capacity to control one's own behaviour plays an important role in this argument. This is, again, a critical moral argument about the specific content of law that depends upon the doctrine of fair opportunity.

It is possible to provide an objective reason for the doctrine of fair opportunity by combining the fact that individuals are by and large capable of guiding their behaviour with a non-moral good. For Hart, the 'general justifying aim' of punishment is to reduce crime. ${ }^{55}$ It is consistent with this good that we should only punish individuals in instances where they have been able to govern their behaviour. If the good to be achieved is deterrent effect, those subject to law can only be deterred if they had opportunity to guide their behaviour one way or another. Nevertheless, the good in this reduction basis is one that we could revise, even to the point of abandonment, without abandoning Hart's concept of law. If the acts that we deem criminal were to cease occurring, there would be no need to deter people from them and thus no good to be achieved. In the hypothetical society of angels posited earlier, there may be no need for punishment at all. Hart's concept of law could still operate in such a society; there would still be a need for laws to govern contracts and wills. If we wish to establish a moral value that we cannot abandon so long as Hart's concept of law holds, we must look elsewhere.

Arguments that deny the idea that human beings are by and large capable of guiding their behaviour are another matter. If an argument were to proceed from the basis that human beings are generally incapable of behaviour guidance, it would be false, provided that we commit to Hart's concept of law and the idea that the truth of moral values depends upon non-moral facts. This falsehood is one that we could not abandon. To be by and large subject to law, is to be by and large capable of guiding one's behaviour.

Similar arguments have been made in instances where a specific group has been oppressed. In the movement towards emancipation some have occasionally, and egregiously, suggested that these groups should not be afforded certain rights on the grounds that the

52 For further examples of Hart's commitment to this doctrine see his discussion of strict liability in 'Acts of Will and Responsibility', Punishment and Responsibility (n 15) 90-112; the arguments in 'Intention and Punishment' on the capacity for punishment to 'goad' behaviour, ibid. 113-35, especially 134-35; the general argument in 'Punishment and the Elimination of Responsibility', ibid 158-85 of which the Wootten debate forms a part; and various comments in 'Changing Conceptions of Responsibility', ibid 186-209.

53 Hart, Law, Liberty (n 12) 21-2.

54 Lord Hope makes a similar point in HJ (Iran) and HT (Cameroon) v Secretary of State for the Home Department [2010] UKSC 31, paras 11, 14 and 21. The involuntary nature of an individual's sexuality formed part of a discussion as to the viability of asylum-seekers relocating within their home state and concealing their sexuality.

55 Hart's position combines Utilitarian and Retributivist elements. Hart's justification for punishment is the societal benefit in crime reduction; in this respect he is Utilitarian. Hart holds that a Retributivist element, punishing a specific individual for wicked acts, is important in achieving that aim. See 'Prolegomenon to the Principles of Punishment', and 'Postscript: Responsibility and Retribution' in Hart, Punishment and Responsibility (n 15) 8-13 and 230-7. 
oppressed group is generally incapable of exercising rational choice with regard to its actions. Such arguments have been made even though the group in question was subject to other legal rules. This was one of a number of arguments put forth by those that opposed women's suffrage. Consider the following claim by James McGrigor Allan:

Woman never escapes from male control, direct or indirect, personal or impersonal, traditionary or present. She is always ruled by some man, either living or governing from the grave ... she embodies her ideal of masculine superiority in some man whose teachings ... she accepts with implicit reverence, making him to all intents and purposes an infallible judge, from whose decision there is no appeal. 56

As far as Allan is concerned, women are always under male 'control'; affording women the right to vote is thus futile. This argument is not only wrongheaded but deeply offensive to modern minds. If we draw out the implications in Hart's work, arguments of this sort are objectively false. It is nonsensical for Allan to make this claim yet accept that women have capacity when it comes to entering a contract or committing criminal acts. ${ }^{57}$ If it were the case that a woman's nature is to 'never escape male control', then no woman should be liable for failing to adhere to criminal law or bound by any contract. There could be no meeting of minds for a valid contract as the woman will have been controlled by some third party. There could be no mens rea for criminal liability as the accused's intentions would not be her own. Law can defensibly acknowledge that an individual might have capacity to perform certain acts and not others. ${ }^{58}$ Law also can, and frequently does, recognise instances of undue influence by one person over another. Allan's claim about the nature of woman goes much further by stating that a woman is 'always ruled by some man'. If this were the case, then there could have been no law for women at the time as women could not individually guide their own behaviour in accordance with legal rules.

If we commit to Hart's account of law, this aspect of Allan's moral argument is false; furthermore we cannot abandon the belief that this argument is false. As a critical moral value that cannot be abandoned, we can say that no group that is generally subject to law should be denied a particular right, privilege or protection in law on the basis that the individuals making up that group cannot by and large guide their own behaviour. ${ }^{59}$

\section{THE PROMOTION OF HUMAN INDIVIDUALITY}

The wrongness of Allan's assertion is based on inconsistency. Under Hart's concept of law, Allan cannot assert that a particular group is incapable of guiding its own behaviour at all

56 Woman Suffrage Wrong in Principle and Practice (Remington \& Co 1890) 125-6. The judiciary was not immune to such attitudes; see Chorlton v Lings (1868) LR 4 CP 374, at 388, Bovill CJ accepted 'that fickleness of judgment and liability to influence' might have been rational grounds for the historic denial of women's suffrage.

57 Others made much of the fact that women were, at the time, not considered fully legally liable in support of arguments against women's suffrage. See the myopic writings of E B Bax, The Legal Subjection of Men (The New Age Press 1908) and The Fraud of Feminism (Grant Richards 1913). Bax argued that since women were afforded certain privileges they ought not to be afforded equality. Bax's arguments are as weak as Allan's, but he does not make the specific claim that I highlight.

58 Hart deals with this; see the doctrine of fair opportunity, discussed above and Hart's postscript to Punishment and Responsibility (n 15) 227-30. Many nineteenth-century arguments against women's suffrage considered women to have capacity in some respects but not others. This attitude was clothed in effusive, but horribly essentialist, language about feminine virtues as distinct from male ones; see J Bridgman and S Millns, Feminist Perspectives on Law: Law's Engagement with the Female Body (Sweet \& Maxwell 1998) 11-27.

59 Certain groups are not fully subject to law's rules. We do not afford full rights or legal capacity to children and other individuals lack capacity. The concept of law which Hart gives us would need to be abandoned if these exceptional cases were to make up the populace generally as nobody subject to law would be capable of being bound by rules or capable of exercising rights. 
and yet consider that group to have legal capacity. This is not yet an account of a moral value that cannot be abandoned along the lines of Hart's chapter IX analysis. Rather than a moral truth, it is a moral falsehood. Furthermore, for a moral truth of this sort to develop, we need a non-moral human aim that cannot be revised to the point of abandonment.

In Law, Liberty and Morality Hart also makes the following claim:

The unimpeded exercise by individuals of free choice may be held a value in itself with which it is prima facie wrong to interfere; or it may be thought valuable because it enables individuals to experiment - even with living - and to discover things valuable both to themselves and others. ${ }^{60}$

Hart's language is tentative. He does not argue strongly for this value. Mill does. Mill argues that experimentation in the exercise of individual choice is to be encouraged; it is only through such experimentation that mankind can evolve and learn. The development of the individual character is, for Mill, 'the chief ingredient of individual and social progress' [emphasis added]. ${ }^{61}$ Allowing 'originality in thought and action' is good for the state as a whole. It is through such freedom that 'new truths' can be discovered and criticism of existing attitudes develops. Like Hart, Mill holds that custom is at the heart of our moral and legal rules. Mill, however, warns that:

[t] he despotism of custom is everywhere the standing hindrance to human advancement, being in unceasing antagonism to that disposition to aim at something better than customary ...62

Hart cannot abandon the fact that moral values are revisable, without giving up his account of moral values. Human beings need some way by which they can suggest improvements to substantive law that would meet the requirements of changes to these facts. Access is needed to a way of thinking that departs from custom if the laws and moral values that custom presents no longer help to achieve a specific good or goods. As a result, critical perspectives on law are non-moral 'goods' for law that cannot be abandoned.

Under reductivist naturalism, the primary means through which we revise our ideas about what is good for us or identify that existing ideas might require revision is through experimentation. ${ }^{63}$ This suggestion fits well with Hart's claims about moral values generally. Such values do not submit to discoverability as metaphysical entities above and beyond our day-to-day living, in the manner that a theist might try to discover the will of God. Unavailable too is a teleological approach or any form of intuitionism. ${ }^{64}$ Yet experimentation in thought and action of the sort described by Mill is suited to the revisability of moral values based on empirical input that we see in reductivist naturalism. Freedom of choice by individuals is a value that law ought to encourage because it is a 'good' for law that individuals have a capacity and an opportunity to experiment with alternatives to traditional approaches. If custom is to be critiqued rather than enjoy the despotic rule that Mill feared, individuality in thought and action is needed. Hart might

60 Hart, Law, Liberty (n 12) 21.

61 Mill (n 26) 50.

62 Ibid 62.

63 For Railton we adapt moral values to meet changes in the reductive basis through feedback gleaned from 'trial and error', 'Moral Realism' (n 11) 179-82; and 'Naturalism' (n 13) 152-8.

64 As noted, Hart rejects 'metaphysical' and teleological approaches, Concept (n 3) 185-94. While Hart felt that intuitionist explanations of moral value are worthy of discussion, Hart 'Morality and Reality' (n 14) 37, intuitionism would fit poorly with the account in chapter IX. 
accept that law could exist among a society of metaphorical sheep, but it seems impossible for any sort of critical morality to do so if we take his claims about moral values seriously. ${ }^{65}$ To accept that critical morality is a non-moral good for law is to also accept that independent thought and the implementation of that thought into lifestyle choices is a nonmoral good for law given Hart's other commitments. ${ }^{66}$

The degree to which law should encourage experimentation might vary. This good is revisable on the basis of other contingent matters of fact. For example, there are powerful reasons why we discourage experimentation with hard drugs, many of which have to do with the harm that such experimentation can cause. Yet Hart cannot utterly abandon the value at stake. Human beings have a capacity to guide their own behaviour; they can slavishly follow custom, or they can be thoughtful and questioning towards it. There are many ways in which law's substantive content might be used to foster the latter attitude. One might argue that this good is achieved in Western liberal democracies through the protection of fundamental freedoms such as freedom of expression, freedoms of religion, belief and opinion and freedom to experiment sexually as alluded to by Hart. Such justification of fundamental freedoms is consistent with the liberal position that Hart endorsed as espoused by Mill and others. ${ }^{67}$ The moral value behind this argument is one that can be revised but not to the point of abandonment. ${ }^{68}$

\section{HART'S THEORY OF MORAL RIGHTS}

Liberal writers such as John Locke have taken the rights of man to be foundational properties that persist regardless of era. For Locke, rights are inalienable and a fundamental part of what it means to be human. This approach is not open to Hart, although rights are certainly important to him. In addition to his endorsement of rights-based constitutional democracy, he dedicates a significant amount of space to the meaning of a legally respected right and the related issue of moral rights as a tool for the evaluation of substantive law. ${ }^{69}$

As Bayles notes, 'no [single] paper represents [Hart's] definitive views [on rights], which have changed over time'. ${ }^{70}$ In Hart's early position, we can see a reductionist tendency. 'Are There Any Natural Rights?' concerns the nature of rights generally rather than specifically legal rights. Hart argues that if there are any moral rights at all, it follows that there is at least one natural right, the equal right of all men to be free'. ${ }^{71}$ This is not reductionist naturalism as the 'one natural right' is not an empirically observable, non-moral fact. Furthermore, the claim that there is at least one natural right suggests that there may be more. Yet, the argument as it developed reduced other rights to this general and equal right to freedom. ${ }^{72}$ The nearest thing to the approach that Hart would later adopt in The Concept of Law is a non-moral condition that Hart adds to the existence of this natural right:

65 Mill uses the same analogy to argue that such a society is undesirable (n 26) 60.

66 Railton alludes to this in relation to law and critique of law, 'Moral Realism' (n 11) 207, fn 42.

67 In addition to Mill, J Milton's Areopagitica (Deighton, Bell \& Co 1973) contains a defence of press freedom similar to the one suggested here. See also the dissenting opinion of O W Holmes in Abrams v United States 250 US 616 (1919).

68 This does not render the principle more important than others; in order to work the contingently true harm principle should take priority in many instances. No hierarchy is implied. The point is that the value persists regardless of changes in contingent matters of fact.

69 See H L A Hart, 'Legal Rights' in Essays on Bentham (Clarendon 1982) 162-93, especially 190-93.

70 M Bayles, Hart's Legal Philosophy: An Examination (Kluwer Academic Publishers 1992) 141.

71 Hart 'Are there Any Natural Rights?' (n 39) 175.

72 This position is closer to non-reductive naturalism; the existence of a moral value must be accepted in order to explain other things. See N Sturgeon, 'Moral Explanations' in G Sayre-McCord (ed), Essays on Moral Realism (Cornell University Press 1988) 229-55. 
This right is one which all men have if they are capable of choice; they have it qua men and not only if they are members of some society or stand in some special relation to each other. ${ }^{73}$

Although Hart's concept of law requires that human beings generally are capable of this sort of choice, ${ }^{74}$ it does not follow from the above statement that all human beings have an equal moral right to freedom wherever we commit to Hart's concept of law. Hart's claim about the 'one natural right' comes with the caveat 'if there are any moral rights at all'. The concept of a 'right', moral or otherwise, does not necessarily exist.

Hart dissociated himself from this position. ${ }^{75}$ Although Hart did not provide specific reasons for this, it would have been difficult to reconcile the belief in a natural right with the anti-metaphysical stance that he later adopted in The Concept of Law. Hart's ultimate position is that a general theory of legal or moral rights is impossible. A large part of what we call rights can be explained through choice theory; the view that legal and moral rights are forms of protected individual choice. Hart maintained that 'ordinary legal rights' fit best with this account. According to Hart, fundamental rights that guarantee protections for the individual against their own state cannot be explained in this way. Hart referred to these as 'immunity rights' ${ }^{76}$

Immunity rights limit '[the legislature's] powers to make (or unmake) the ordinary law, where to do so would deny to individuals certain freedoms and benefits' ${ }^{77}$ Immunity rights include security of life and person, education, equality of treatment and freedom from arbitrary arrest. ${ }^{78}$ Crucially for the purposes of this investigation, Hart notes that his analysis of rights has relevance beyond those that form part of existing law. The notion of an immunity right helps to describe existing legal rights. It also provides a means of critiquing law. As Hart notes 'law . . . is too important a thing to leave to lawyers'; ${ }^{79}$ some fundamental rights used to critique existing law are also based in the notion of 'immunity' rather than 'choice'.

The moral right of individuals to have certain immunities from the state is based on 'essentials of human well being. ${ }^{80}$ In chapter IX Hart linked the reasons for these sorts of moral values to contingent facts about human nature. By way of illustration, rights to security of life and person are immunity rights according to Hart. ${ }^{81}$ Their focus is to guarantee that individuals will not be subjected to certain types of harm or degradation. This type of right

73 Hart 'Are there Any Natural Rights?' (n 39) 175.

74 'Choice' and 'behaviour guidance' are not synonymous. Hart discusses the right to behave as one wishes provided that one is capable of exercising choice in the matter. In what follows on 'choice-based rights', Hart specifically refers to a right to act in accordance with choice, rather than a right to simply will an outcome. Reference to 'choice' should be taken to read 'choice where this manifests itself in behaviour'.

75 Hart, Essays (n 12) 17.

76 Hart, 'Legal Rights' (n 69) 190.

77 Ibid.

78 Ibid. The right to a fair trial, the right to privacy and the right to compensation for miscarriages of justice among others are also likely immunity rights. These examples are from the European Convention on Human Rights, see D J Harris, M O’Boyle and C Warbrick, Law of the European Convention on Human Rights (2nd edn, Oxford University Press 2009) 201-330, 361-424, 557-576, 750.

79 Hart, 'Legal Rights' (n 69) 192.

80 Ibid 190.

81 See United Nations Declaration on the Protection of All Persons from Being Subjected to Torture and Other Cruel, Inhuman or Degrading Treatment or Punishment, and Article 3 of the European Convention on Human Rights. 
informs moral debate on the death penalty 82 and the use of interrogation techniques, including torture. ${ }^{83}$ For Hart, that human beings are physically vulnerable is a contingent truth. If this underlying fact were to cease being true, this would have serious, potentially fatal, consequences for moral arguments that security of person ought to be protected. ${ }^{84}$

We could reduce many of these immunity rights to the sorts of non-moral, contingent facts about human nature that Hart identifies in chapter IX and non-moral goods such as survival or flourishing. That these immunity rights ought to be protected may be an objective moral truth, but it is revisable to the point of abandonment.

The non-moral fact that underlies choice-based rights is one that Hart cannot revise to the point of abandonment, on pain of giving up his concept of law. ${ }^{85}$ Certain rights are reducible to 'choices'. If it were to be empirically observable that human beings cannot guide their own behaviour, then we would not only have to give up choice-based rights and any argument based on them for critiquing law, we would also have to give up Hart's concept of law itself. Nevertheless, two problems arise if we wish to turn the protection of choice-based rights into permanent moral values.

The first problem is that the mere existence of a human capacity to exercise choice that underlies choice-based rights will not turn into a proposition that we ought to respect such rights unless there is some non-moral good to be achieved by doing so. It may be possible to address this by coupling choice-based rights with an argument made earlier. It is a good, wherever there is law, for individuality in human thought and action to be encouraged, the argument might go. Choice-based rights give effect to human choices in thought and action and so, the argument would continue, choice-based rights ought to be protected as a moral value that we cannot revise to the point of abandonment. One might extend this argument to certain immunity rights on the basis that these also help to foster and encourage individuality through experimentation in thought and action.

The second problem concerns the very notion of 'rights'. Rights are useful tools that we employ in moral argument and in law. Yet, there would not appear to be any non-moral fact that Hart is committed to that would require the existence of a right, rather than some other tool, as a means of promoting this good.

What we can say is that the starting point for $a$ system of choice-based moral rights exists wherever there is law. Whether such a system grows and flourishes is a matter of contingent fact, but the basis for this system simply must be there if Hart's concept of law holds. As a result, whenever we talk of moral rights that citizens have against other citizens we are talking about something that has its basis in a truth about human nature that we cannot abandon if we accept Hart's account of the concept of law. So long as we accept the idea of rights at all, there is the possibility for a lasting moral truth in the notion that choice-based rights ought to be protected as should those immunity rights that help to foster a spirit of critical reflection.

82 See W Schabas, The Death Penalty as Cruel Treatment and Torture: Capital Punishment Challenged in the World's Courts (Northeastern University Press 1996).

83 See, K J Greenberg (ed), The Torture Debate in America (Cambridge University Press 2006) and S Levinson (ed), Torture: A Collection (Oxford University Press 2004); in particular H Shue, 'Torture', ibid 47-60; A Dershowitz 'Tortured Reasoning', ibid 257-80; and E Scarry, 'Five Errors in the Reasoning of Alan Dershowitz', ibid 281-90.

84 Some argue that choice theory can account for 'immunity' rights. See P Graham, 'The Will Theory of Rights: A Defence' (1996) 15(3) Law and Philosophy 257; and H Steiner 'Are There Still Any Natural Rights?' in Kramer et al (n 37) 239-250.

85 As with moral values, no hierarchy is created between different types of rights as a result. 


\section{Conclusion: Hart's liberalism and non-evaluative description}

The reading of Hart's work presented here places his claims about reasons for moral values to the fore. Read this way, it is possible for Hart's philosophy to support lasting, moral values about law of the sort that his liberal politics demands.

The methodology employed has built upon Hart's own claims about reasons for moral values. Nevertheless, the result rests uneasily alongside Hart's desire to distinguish descriptive accounts of law from claims as to what law's substantive content ought to be.

By linking the reasons behind moral values to matters of fact and human aims, as Hart does in chapter IX, questions about what law is and reasons for moral values become inextricably linked. Any conceptual analysis of law will make tacit assumptions about human nature and the world we live in; some of these facts must remain true if the analysis is to remain accurate. If one accepts Hart's account of reasons for moral values, these facts are likely to bring with them a number of objective reasons as to why the specific content of law ought to adhere to certain values. Some tools for what law ought to be are furnished by the account of the concept.

In reading Hart's works together, we are left with a choice. Our first option is to take his claims about reasons for moral values seriously. Under this approach we can link those values to a defensible liberal position, but this comes at a price; we must downplay or ignore the idea that descriptive accounts of law belong in a different realm to evaluative claims about law's content. Our second option is to strictly adhere to Hart's distinction between conceptual analysis of law and evaluative perspectives on law. This option requires us to disregard the reasons that he gives for moral values and leaves the core liberal tension identified earlier unresolved.

Each reading involves prioritising some aspects of Hart's work over others. For those that regard it as important to identify Hart as a positivist, it should be noted that the reading presented here does not prevent us from doing so. As John Gardner has pointed out, a commitment to positivism does not require the denial of a connection between law and morality, even a necessary one. ${ }^{86}$ There is nothing in this reading that suggests the validity of a legal norm is anything other than its source. Faced with the choice of disregarding Hart's account of rights or his distinction between description and evaluation, there is more to be gained by taking the account of moral values seriously. The reading that I have presented allows us to contextualise Hart's work as an important part of a liberal tradition Hart wished to join. The alternative not only requires us to read his analysis of the concept of law as an enterprise distinct from his critical perspective, it requires us to accept a deep conflict between the claims in chapter IX about contingency of moral principles and his critical need for lasting moral values.

86 John Gardner ‘51/2 Myths about Legal Positivism’ (2001) 46 American Journal of Jurisprudence 199, at $222-25$. 